\title{
MUTU ARANG AKTIF DARI SERBUK GERGAJI KAYU
}

\section{(The Quality Sawdust Activated Charcoal)}

\author{
Oleh/By: \\ Gustan Pari $^{1)}$, Diah Tri Widayati ${ }^{2)}$ \& Masato Yoshida ${ }^{3)}$ \\ ${ }^{1)}$ Pusat Litbang Hasil Hutan, Jl. Gunung Batu No. 5 Bogor, Telp/Fax: 8633413-8633378 \\ ${ }^{2)}$ Universitas Gajah Mada, Yogyakarta \\ ${ }^{33}$ Nagoya University - Japan
}

Diterima 13 Agustus 2009, disetujui 14 Oktober 2009

\begin{abstract}
This study was carried out to look at the effect of activation temperature and duration on the yield and qualities of activated charcoal of sawdust. Such activation, following the manufacture af sawdust charcoal, was conducted in an electrically heated stainless steel retort in that the temperature varied at three level (i.e. 700,800 and $900^{\circ} \mathrm{C}$ ), each held for 30, 60 and 90 minute duration. Activator agent used was $\mathrm{H}_{3} \mathrm{PO}_{4} 15 \%$.

The results showed that the optimum activation condition to acquire activated charcoal with the best qualities was at $900^{\circ} \mathrm{C}$ for 90 minute duration. This condition afforded the yield of activated sawdust charcoal at $11.33 \%$, moisture content $19.26 \%$, ash content $41.90 \%$, volatile matter $9.25 \%$, and fixed carbon $48.85 \%$. Also as such, its adsorptive capacity on iodine was $1171.5 \mathrm{mg} / \mathrm{g}$ (i.e, satisfying the Japan standard requirement), on benzene $10.93 \%$, of $\mathrm{CHCl}_{3}$ $30.38 \%$ and on methylene blue $149.98 \mathrm{mg} / \mathrm{g}$. Based on the properties and methylene blue adsorptive capacity, the experimented activated sawdust charcoal can be used for the purification of dye coloring matters and as poultry supplement.
\end{abstract}

Keywords: Wood sawdust, activated charcoal, adsorptive capacity, dye purification

\begin{abstract}
ABSTRAK
Tulisan ini mengemukakan hasil penelitian pembuatan arang aktif dari serbuk gergaji kayu, dengan tujuan untuk mengetahui pengaruh suhu dan lama waktu aktivasi terhadap hasil dan mutu arang aktif yang dihasilkan dari arang serbuk kayu gergajian. Proses pembuatan arang aktif dilakukan dengan menggunakan retor yang terbuat dari baja tahan karat yang dilengkapi dengan elemen listrik pada suhu 700,800 dan $900{ }^{\circ} \mathrm{C}$ dengan lama waktu aktivasi masing-masing selama 30, 60 dan 90 menit. Bahan pengaktif yang digunakan adalah larutan $\mathrm{H}_{3} \mathrm{PO}_{4} 15 \%$.

Hasil penelitian menunjukkan bahwa kondisi terbaik untuk membuat arang katif dihasilkan pada suhu $900^{\circ} \mathrm{C}$, dengan lama waktu aktivasi 90 menit, yang menghasilkan rendemen sebesar $11,33 \%$, kadar air 19,26\%, kadar abu 41,90\%, kadar zat terbang $9,25 \%$, kadar karbon terikat 48,85\%. Daya serap arang aktif terhadap benzena sebesar 10,93\%, $\mathrm{CHCl}_{3}$ sebesar $30,38 \%$, daya serap iodium $1171,5 \mathrm{mg} / \mathrm{g}$ (memenuhi syarat standar Jepang) dan daya serap terhadap biru metilena sebesar 149,98 mg/g. Berdasarkan sifat dan besarnya daya serap terhadap biru metilena, maka arang aktif dari serbuk gergaji kayu ini dapat digunakan untuk penjernihan zat warna dan sebagai campuran pohon ternak.
\end{abstract}

Kata kunci: Serbuk gergaji, arang aktif, daya serap, pirifikasi zat warna. 


\section{PENDAHULUAN}

Salah satu kebijakan Departemen Kehutanan adalah memanfaatkan kayu seoptimal mungkin (zero waste) yang berarti bahwa semua industri pengolahan kayu baik besar maupun kecil harus berusaha supaya meminimalisir produksi limbah kayu. Namun demikian kenyataan di lapangan umumnya rendemen industri penggergajian kayu masih berkisar dari $50-60 \%$, di mana sebanyak $15-20 \%$ terdiri dari serbuk kayu gergajian. Diperkirakan jumlah limbah serbuk kayu gergajian di Indonesia sebanyak 0,78 juta $\mathrm{m}^{3} /$ th. (Pari and Roliadi, 2004). Untuk industri besar dan terpadu, limbah serbuk kayu gergajian sudah dimanfaatkan menjadi bentuk briket arang dan dijual secara komersial. Namun untuk industri penggergajian kayu skala industri kecil yang jumlahnya mencapai ribuan unit dan tersebar di pedesaan, limbah tersebut belum dimanfaatkan secara optimal. Salah satu usaha meningkatkan nilai tambah dari serbuk gergajian ini adalah dibuat arang aktif.

Penelitian terdahulu menunjukkan bahwa arang aktif dapat dibuat dari serbuk kayu gergajian sengon dan tusam yang diproses dengan cara kimia dan fisika menghasilkan daya serap terhadap iodium bervariasi antara 650 - $890 \mathrm{mg} / \mathrm{g}$ (Pari, 1992 dan 1996). Mutu arang aktif ini memenuhi standar Indonesia (Anonim, 1995) dan Amerika Serikat (Anonim, 1978), tetapi tidak memenuhi syarat standar Jepang (Anonim, 1967) karena daya serapnya kurang dari $1050 \mathrm{mg} / \mathrm{g}$. Untuk meningkatkan mutu arang aktif dari serbuk kayu gergaji, dalam penelitian ini dilakukan pembuatan arang aktif dari serbuk gergaji dengan cara kombinasi kimia dan fisika dengan tujuan mengetahui pengaruh suhu dan lama waktu aktivasi terhadap mutu dan struktur arang aktif serta kemungkinan pemanfaatannya sebagai campuran pakan ternak ditinjau dari sifat arang aktif yang dihasilkan.

\section{BAHAN DAN METODA}

\section{A. Bahan dan Alat}

Bahan penelitian yang digunakan dalam penelitian ini adalah serbuk kayu gergajian yang diambil dari beberapa industri penggergajian skala menengah dan skala kecil di Indonesia yang kemudian saling dicampurkan. Bahan kimia yang digunakan diantaranya adalah asam fosfat, kalium iodida, iodium, natrium tio sulfat, benzena, $\mathrm{CHCl}_{3}$ dan biru metilina. Asam fosfat $\left(\mathrm{H}_{3} \mathrm{PO}_{4}\right)$ digunakan pada proses aktivasi arang, sedangkan bahan selainnya digunakan untuk menentukan kualitas arang aktif terkait dengan daya serapnya terhadap larutan dan gas. Peralatan yang digunakan di antaranya adalah retor, desikator, cawan porselin, tanur pengarangan dan oven untuk menentukan kadar air, abu, karbon terikat dan zat terbang.

\section{B. Metode Penelitian}

\section{Pembuatan arang serbuk gergaji}

Serbuk gergaji kayu diarangkan dalam tanur (kiln) semi kontinu (Gambar 1) yang terbuat dari plat besi dan ditutup dengan plat seng. Kiln semi kontinu ini terdiri dari empat bagian yaitu cerobong, tempat contoh, ruang karbonisasi dan tempat air sebagai pendingin. Pertama ruang karbonisasi dipanaskan, kemudian contoh serbuk gergaji dimasukkan ke dalam tempat 
contoh. Setelah ruang karbonisasi panas, contoh diturunkan ke ruang karbonisasi tersebut sambil dilakukan pengadukan agar proses karbonisasinya merata dan sempurna. Apabila serbuk sudah hitam semua, arang yang dihasilkan tersebut merata dan dimasukkan ke dalam bak yang berisi air. Demikian sampai contoh serbuk habis dikarbonisasi.

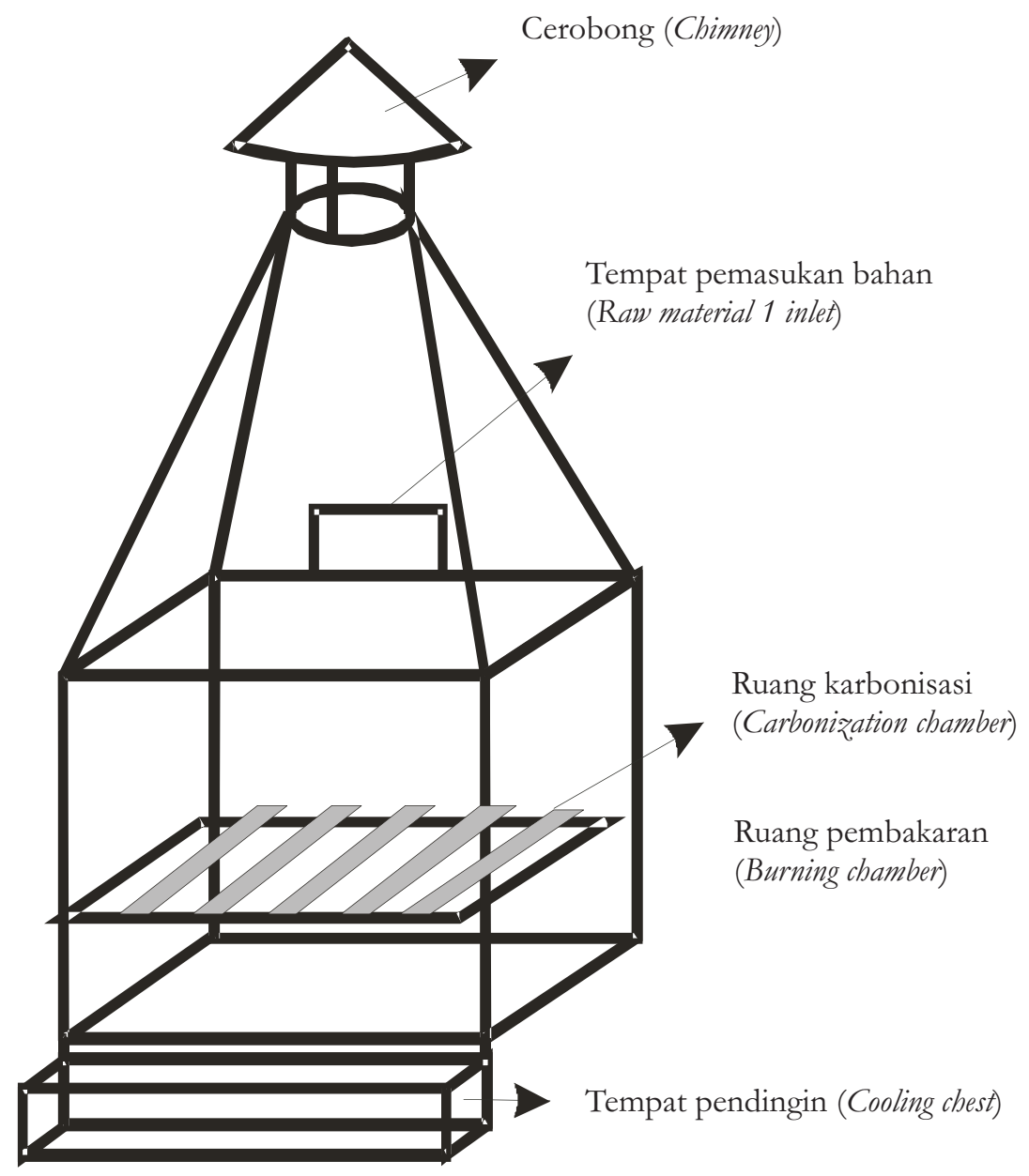

Gambar 1. Tungku arang dari sistem semi kontinyu Figure 1. Charcoal kiln with semi continous system 


\section{Pembuatan arang aktif}

Arang serbuk kayu gergajian yang dihasilkan direndam dalam larutan $\mathrm{H}_{3} \mathrm{PO}_{4} \quad 15 \%$ selama 24 jam, setelah ditiriskan (dibiarkan) selama satu hari, selanjutnya dimasukan ke dalam retort kapasitas $0,5 \mathrm{~kg}$ yang terbuat dari baja tahan karat (Pari, et al., 2006) dan dipanaskan pada suhu $700^{\circ} \mathrm{C}, 800^{\circ} \mathrm{C}$ dan $900^{\circ} \mathrm{C}$. Setelah suhu retor tercapai, dialirkan uap air $\left(\mathrm{H}_{2} \mathrm{O}\right)$ lewat jenuh bertekanan 0,5 kg/ $\mathrm{cm}^{2}$ ke dalamnya masing-masing selama 30, 60 dan 90 menit, dari ketel uap air. Setiap taraf dari kombinasi suhu aktivasi dan waktu pengaliran uap air (waktu aktivasi) dilakukan ulangan sebanyak dua kali.

\section{Pengujian kualitas arang dan arang aktif}

Arang yang dihasilkan di uji kualitasnya berdasarkan Standar ASTM (Anonim, 1982) yang meliputi penetapan kadar air, zat terbang, abu, dan kadar karbon terikat. Sedangkan kualitas arang aktif di uji berdasarkan standar Indonesia (Anonim, 1995) yang meliputi penetapan kadar air, abu, zat terbang, karbon, daya serap terhadap iodium benzene, $\mathrm{CHCl}_{3}$ dan biru metilena. Untuk mengetahui pengaruh perlakuan suhu aktivasi dan lama waktu aktivasi terhadap mutu arang aktif yang dihasilkan, dilakukan penelaahan sidik ragam yang dilanjutkan dengan uji regresi dan uji beda nyata jujur (Sudjana, 1980). Untuk melihat proses pembentukan pori dilakukan pengujian dengan menggunakan scanning electron microscope (SEM).

\section{HASIL DAN PEMBAHASAN}

\section{A. Sifat Arang Serbuk Gergaji Kayu}

Arang serbuk gergaji yang dihasilkan memiliki sifat yang memenuhi syarat untuk dapat dijadikan arang aktif karena kadar karbon terikatnya sebesar 72,32\% lebih dari yang di persyaratkan (Smisek dan Cerny, 1970) yaitu sebesar 70\%. Besarnya kadar karbon ini akan berpengaruh positip pada rendemen dan mutu arang aktif. Selain kadar karbon, sifat arang yang lain adalah kadar air 3,07\%, kadar abu 4,50\%, kadar zat terbang 23,68\% dan rendemen arang yang dihasilkan adalah sebesar 21,27\%. Besarnya kadar zat terbang ini disebabkan oleh rendahnya suhu karbonisasi yang hanya mencapai $350^{\circ} \mathrm{C}$. Hal ini tidak terlalu mengganggu mutu arang aktif karena pada waktu aktivasi kadar zat terbang ini akan terurai. Khusus untuk kadar abu, disyaratkan sebesar 1 - 2\% (Smisek dan Cerny, 1970). Untuk hal itu dalam proses pembuatan arang aktifnya digunakan proses pirolisis lambat (slow pyrolysis). Beberapa hasil penelitian menunjukkan bahwa, walaupun kadar abu arangnya tidak memenuhi persyaratan namun tetap dapat dibuat arang aktif (Komarayati, et al. 1998 dan Pari, 1999) dengan sifat dan mutu yang memenuhi standar Indonesia (Anonim, 1995).

\section{B. Rendemen Arang Aktif}

Rendemen arang aktif yang dihasilkan berkisar antara 11,33 - 41,00\% (Tabel 1). Berdasarkan penelaahan sidik ragam ternyata semua perlakuan (suhu aktivasi dan lama waktu aktivasi) dan interaksi ke dua faktor tersebut sangat berpengaruh terhadap rendemen yang 
dihasilkan (Tabel 2). Rendemen tertinggi (41,00\%) dihasilkan oleh arang yang diaktivasi pada suhu $700^{\circ} \mathrm{C}$ dengan lama waktu aktivasi 30 menit dan rendemen yang terendah $(11,33 \%)$ dihasilkan oleh arang yang daktivasi pada suhu $900^{\circ} \mathrm{C}$ dengan lama waktu aktivasi 90 menit. Walaupun sidik regresi menunjukkan tidak ada perbedaan yang nyata untuk suhu aktivasi terhadap rendemen arang aktif yang dihasilkan, tetapi terdapat kecenderungan rendemen yang dihasilkan semakin menurun (Tabel 3). Sedangkan untuk untuk lama waktu aktivasi, perhitungan sidik regresinya menunjukkan adanya perbedaan yang nyata terhadap rendemen arang aktif dengan kecenderungan yang juga makin menurun dengan makin lamanya waktu aktivasi (Tabel 4). Penurunan rendemen ini menunjukkan bahwa reaksi antara atom $\mathrm{C}$ (karbon) pada arang dengan uap $\mathrm{H}_{2} \mathrm{O}$ makin intensif terutama pada suhu $900^{\circ} \mathrm{C}$, dan waktu aktifasi 90 menit sehingga mengubah sebagaian karbon tersebut (padat) menjadi bentuk tidak padat (gas).

Hasil uji beda nyata jujur (BNJ) menunjukkan bahwa tidak semua perlakuan dan interaksinya menyebabkan perbedaan rendemen arang aktif yang nyata (Tabel 6). Arang yang diaktivasi pada suhu $700^{\circ} \mathrm{C}$ dengan waktu aktivasi selama 60 menit (a1b2) sebesar 30,53\% tidak menghasilkan rendemen yang berbeda dibandingkan dengan arang yang diaktivasi pada suhu $800^{\circ} \mathrm{C}$ dengan waktu aktivasi selama 30 dan 60 menit (a2b1 dan a2b2) sebesar 31,00 dan $30,80 \%$.

\section{Kadar Air}

Kadar air arang aktif yang dihasilkan berkisar antara 7,37 - 19,26\% (Tabel 1). Kadar air arang aktif yang memenuhi syarat standar Indonesia (Anonim, 1995) adalah arang yang diaktivasi pada suhu $700^{\circ} \mathrm{C}$ dengan lama waktu aktivasi selama 30, 60, 90 menit dan arang yang diaktivasi pada suhu $800^{\circ} \mathrm{C}$ dengan lama waktu aktivasi 30 menit karena kadarnya kurang dari $15 \%$. Berdasarkan penelaahan sidik ragam ternyata semua perlakuan dan interaksinya sangat berpengaruh terhadap kadar air yang dihasilkan (Tabel 2). Kadar air tertinggi (19,26\%) dihasilkan oleh arang yang diaktivasi pada suhu $900^{\circ} \mathrm{C}$ dengan waktu aktivasi selama 90 menit, kadar air yang terendah $(7,37 \%)$ dihasilkan oleh arang yang diaktivasi pada suhu $700^{\circ} \mathrm{C}$ dengan lama waktu aktivasi 60 menit. Dari uji regresi ternyata makin tinggi suhu dan lama waktu aktivasi, kadar air yang dihasilkan cenderung makin naik (Tabel 3 dan 4). Peningkatan kadar air ini selain disebabkan terjadinya peningkatan sifat higroskopis arang aktif terhadap uap air, juga disebabkan terjadinya pengikatan molekul air oleh 6 atom karbon yang telah diaktivasi (Pari, et al. 1996). Apabila hasil ini dibandingkan dengan arang aktif komersial sebesar 20,87\%, maka kadar air hasil penelitian masih lebih rendah. 


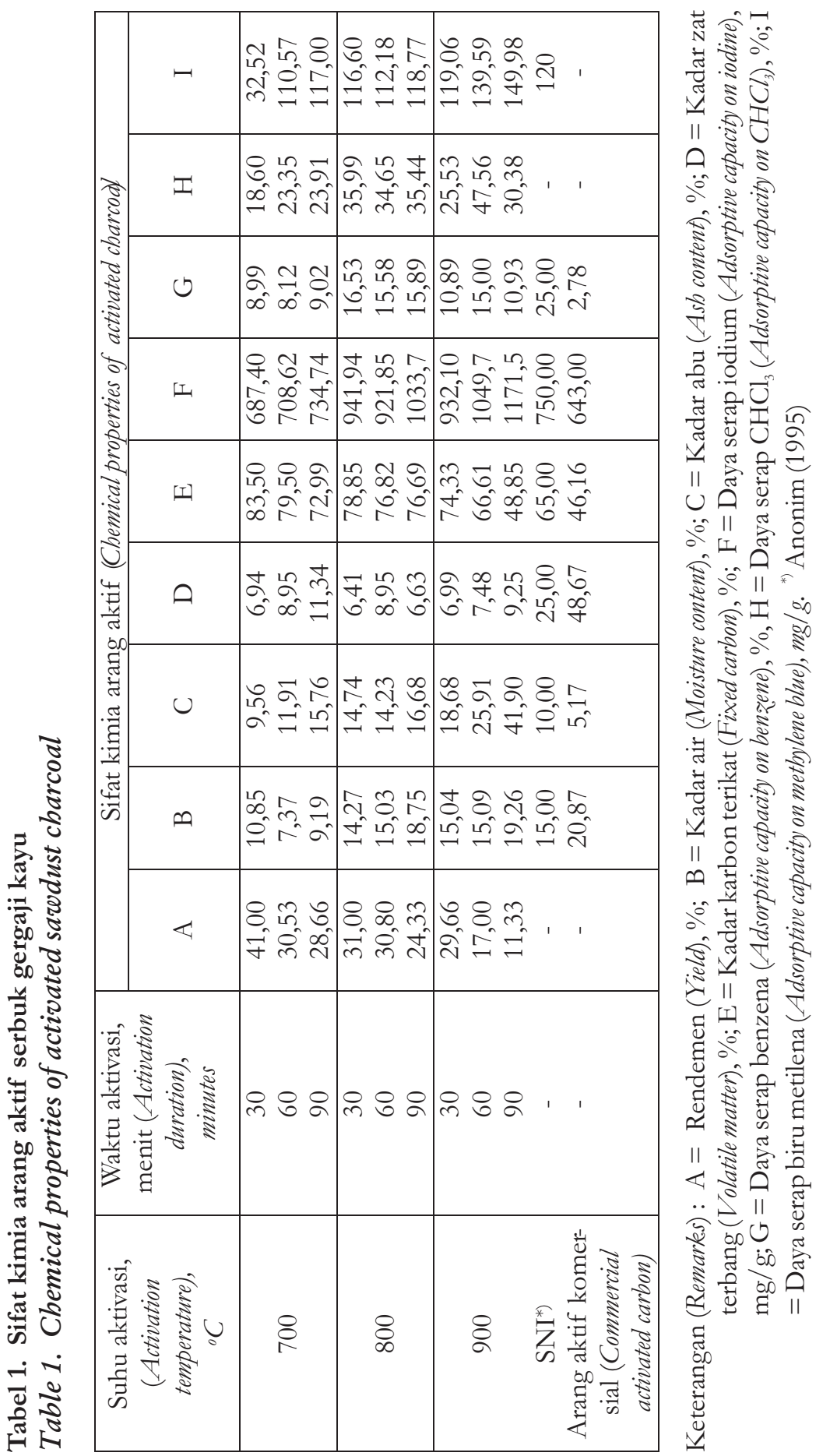


Hasil uji BNJ menunjukkan bahwa tidak semua perlakuan dan interaksinya menyebabkan perbedaan kadar air yang nyata (Tabel 6). Sebagai contoh adalah arang yang diaktivasi pada suhu $800^{\circ} \mathrm{C}$ dengan lama waktu 60 menit (a2b2) sebesar 15,03\% tidak berbeda nyata dibandingkan dengan arang yang diaktivasi pada suhu $900^{\circ} \mathrm{C}$ dengan lama waktu 30 dan 60 menit (a3b1 dan a3b2) sebesar 15,04 dan 15,09\%.

Table 2. Ringkasan sidik ragam sifat arang aktif dari serbuk gergaji kayu

Table 2. Summarizing analysis of variance on properties of activated sawdust Charcoal

\begin{tabular}{|c|c|c|c|c|}
\hline No & Sifat (Properties) & $\begin{array}{l}\text { Perlakuan } \\
\text { (Treatment) }\end{array}$ & $\begin{array}{l}\text { Kuadrat tengah } \\
\text { (Mean square) }\end{array}$ & $\begin{array}{c}\text { F-hitung } \\
\text { (F-calculated) }\end{array}$ \\
\hline 1 & Rendemen (Yield), \% & $\begin{array}{c}\mathrm{A} \\
\mathrm{B} \\
\mathrm{AB}\end{array}$ & $\begin{array}{c}307,82 \\
237,20 \\
28,09\end{array}$ & $\begin{array}{c}314,86^{* *} \\
242,63^{* *} \\
28,73^{* *}\end{array}$ \\
\hline 2 & $\begin{array}{l}\text { Kadar air (Moisture con- } \\
\text { tent), } \%\end{array}$ & $\begin{array}{c}\mathrm{A} \\
\mathrm{B} \\
\mathrm{AB}\end{array}$ & $\begin{array}{c}99,12 \\
14,96 \\
5,87\end{array}$ & $\begin{array}{c}79,75^{* *} \\
12,06 * * \\
4,73^{* *}\end{array}$ \\
\hline 3 & $\begin{array}{c}\text { Kadar abu }(\text { Ash content }), \\
\%\end{array}$ & $\begin{array}{c}\mathrm{A} \\
\mathrm{B} \\
\mathrm{AB}\end{array}$ & $\begin{array}{c}462,82 \\
173,62 \\
65,85\end{array}$ & $\begin{array}{l}629,25 * * \\
236,05^{* *} \\
89,53 * *\end{array}$ \\
\hline 4 & $\begin{array}{l}\text { Kadar zat terbang } \\
\text { (Volatile matter), } \%\end{array}$ & $\begin{array}{c}\mathrm{A} \\
\mathrm{B} \\
\mathrm{AB}\end{array}$ & $\begin{array}{l}4,75 \\
8,45 \\
4,48\end{array}$ & $\begin{array}{c}9,84^{* *} \\
17,60^{* *} \\
9,33^{* *}\end{array}$ \\
\hline 5 & $\begin{array}{l}\text { Kadar karbon terikat } \\
\text { (Fixed carbon), \% }\end{array}$ & $\begin{array}{c}\mathrm{A} \\
\mathrm{B} \\
\mathrm{AB}\end{array}$ & $\begin{array}{c}402,26 \\
323,92 \\
50,50\end{array}$ & $\begin{array}{c}52,67 * * \\
42,45^{* *} \\
6,62^{* *}\end{array}$ \\
\hline 6 & $\begin{array}{l}\text { Daya serap iodium } \\
\text { (Adsorptive capacity on } \\
\text { iodine), } \mathrm{mg} / \mathrm{g}\end{array}$ & $\begin{array}{c}\mathrm{A} \\
\mathrm{B} \\
\mathrm{AB}\end{array}$ & $\begin{array}{c}188772,53 \\
24989,26 \\
5956,25\end{array}$ & $\begin{array}{c}2598,46^{* *} \\
343,96^{* *} \\
81,98^{* *}\end{array}$ \\
\hline 7 & $\begin{array}{l}\text { Daya serap benzena } \\
\text { (Adsorptive capacity on } \\
\text { benzene), } \%\end{array}$ & $\begin{array}{c}\mathrm{A} \\
\mathrm{B} \\
\mathrm{AB}\end{array}$ & $\begin{array}{c}79,72 \\
1,52 \\
5,31\end{array}$ & $\begin{array}{c}78,36^{* *} \\
1,51 \\
5,25^{* *}\end{array}$ \\
\hline 8 & $\begin{array}{l}\text { Daya serap } \mathrm{CHCl}_{3} \\
\text { (Adsorptive capacity on } \\
(\mathrm{CHCl})_{3}, \%\end{array}$ & $\begin{array}{c}\mathrm{A} \\
\mathrm{B} \\
\mathrm{AB}\end{array}$ & $\begin{array}{l}337,66 \\
110,91 \\
87,51\end{array}$ & $\begin{array}{c}229,07 * * \\
75,44 * * \\
59,53 * *\end{array}$ \\
\hline 9 & $\begin{array}{l}\text { Daya serap biru metilena } \\
\text { (Adsorptive capacity on } \\
\text { methylene blue), } \mathrm{mg} / \mathrm{g}\end{array}$ & $\begin{array}{c}\mathrm{A} \\
\mathrm{B} \\
\mathrm{AB}\end{array}$ & $\begin{array}{l}3716,25 \\
2582,02 \\
1179,58\end{array}$ & $\begin{array}{c}2870,13^{*} \\
1994,14^{* *} \\
911,01 * *\end{array}$ \\
\hline
\end{tabular}

Keterangan (Remarks) : $\mathrm{A}=$ Perlakuan suhu aktivasi (Activation temperature treatment) $\mathrm{B}=$ Waktu aktivasi (Activationduration treatment); $\mathrm{AB}=$ Interaksi (Interaction) $^{* *}=$ Sangat nyata (Highly significant); * = Nyata (Significant) 


\section{Kadar Abu}

Kadar abu arang aktif yang dihasilkan berkisar antara 9,56 - 41,90\% (Tabel 1). Nilai kadar abu yang memenuhi syarat standar Indonesia (Anonim, 1995) adalah hanya arang yang diaktivasi pada suhu $700^{\circ} \mathrm{C}$ dengan waktu aktivasi selama 30 menit, karena kadarnya kurang dari $10 \%$. Berdasarkan penelaahan sidik ragam ternyata semua perlakuan dan interaksinya berpengaruh nyata terhadap kadar abu yang dihasilkan (Tabel 2). Kadar abu tertinggi $(41,90 \%)$ dihasilkan oleh arang yang diaktivasi pada suhu $900^{\circ} \mathrm{C}$ dengan waktu aktivasi selama 90 menit dan kadar abu yang terendah (9,56\%) dihasilkan oleh arang yang diaktivasi pada suhu $700^{\circ} \mathrm{C}$ dengan lama waktu aktivasi 30 menit. Tingginya kadar abu yang dihasilkan dapat mengurangi daya adsorpsi arang aktif, karena pori arang aktif terisi oleh mineral-mineral logam seperti $\mathrm{K}, \mathrm{Na}$, Ca dan Mg (Smisek dan Cerny, 1970). Uji sidik regresi menunjukkan bahwa makin tinggi aktivasi dan makin lama waktu aktivasi, kadar abu arang aktif yang dihasilkan makin naik (Tabel 3 dan 4). Peningkatan kadar abu ini menunjukkan adanya proses oksidasi lebih lanjut terutama terhadap partikel halus (kecil), dan diduga adanya reaksi antara atom $\mathrm{C}$ (padatan pada arang) dengan uap air $\left(\mathrm{H}_{2} \mathrm{O}\right)$ yang menyebabkan penurunan rendemen/berat arang(Tabel 3 dan 6), sedangkan bahan abu relatif stabil terhadap suhu tinggi dan perlakuan uap panas lewat jenuh. Apabila hasil ini dibandingkan dengan arang aktif komersial sebesar 5,17\%, maka kadar abu hasil penelitian lebih tinggi, tetapi apabila dibandingkan dengan hasil penelitian (Pari et al., 2000), maka kadar abunya tidak jauh berbeda yaitu antara $11,81-16,90 \%$.

Hasil uji BNJ menunjukkan bahwa tidak semua perlakuan dan interaksinya menyebabkan perbedaan kadar abu yang nyata (Tabel 6). Sebagai contoh adalah arang yang diaktivasi pada suhu $800^{\circ} \mathrm{C}$ dengan lama waktu 60 menit (a2b2) sebesar 14,23\% tidak berbeda nyata dibandingkan dengan arang yang diaktivasi pada suhu $800^{\circ} \mathrm{C}$ dengan lama waktu 30 (a2b1) sebesar 14,74\% dan arang yang diaktivasi pada suhu $700^{\circ} \mathrm{C}$ dengan lama waktu 90 (a1b3) sebesar 15,76\%.

\section{E. Kadat Zat Terbang}

Kadar zat terbang arang aktif yang dihasilkan berkisar antara 6,41 - 11,34\% (Tabel 1). Nilai kadar zat terbang yang dihasilkan ini semuanya memenuhi syarat standar Indonesia (Anonim, 1995) karena kadarnya tidak lebih dari 25\%. Berdasarkan penelaahan sidik ragam ternyata semua perlakuan dan interaksinya berpengaruh nyata terhadap kadar zat terbang arang aktif yang dihasilkan (Tabel 2). Kadar zat terbang tertinggi (11,34\%) dihasilkan oleh arang yang diaktivasi pada suhu $700^{\circ} \mathrm{C}$ dengan lama waktu aktivasi 90 menit dan kadar zat terbang yang terendah $(6,41 \%)$ dihasilkan oleh arang yang diaktivasi pada suhu $800^{\circ} \mathrm{C}$ dengan lama waktu aktivasi 30 menit. Walaupun penelaahan sidik regresi menunjukkan tidak ada perbedaan yang nyata untuk suhu aktivasi terhadap kadar zat terbang arang aktif, tetapi terdapat kecenderungan kadar zat terbang yang dihasilkan makin menurun (Tabel 3). Sedangkan untuk untuk lama waktu aktivasi, perhitungan sidik regresinya menunjukkan adanya perbedaan yang nyata terhadap kadar zat terbang arang aktif dengan kecenderungan yang juga makin menurun dengan makin lamanya waktu aktivasi (Tabel 4). Penurunan kadar zat terbang ini mengindikasikan bahwa laju reaksi antara atom karbon dengan uap $\mathrm{H}_{2} \mathrm{O}$ makin 
intensif terutama pada suhu $900^{\circ} \mathrm{C}$. Tinggi rendahnya kadar zat terbang yang dihasilkan menunjukkan juga permukaan arang aktif masih ditutupi oleh senyawa non karbon yang bermuatan negatif sehingga mempengaruhi kemampuan daya serapnya. tetapi sifat ini akan berdampak positif untuk mengikat senyawa berlebihan yang dapat menimbulkan penyakit pada ternak seperti diare dan kegagalan reproduksi, sehingga dapat meningkatkan produksi dan kualitas daging dan telur ayam apabila pada pakan ternaknya ditambahkan arang dan cuka kayu (Takahashi and Hirowaka, 2009).

Apabila hasil ini dibandingkan dengan arang aktif komersial sebesar 48,67\%, maka kadar zat terbang hasil penelitian masih lebih rendah.

Hasil uji BNJ menunjukkan bahwa tidak semua perlakuan dan interaksinya memberikan perbedaan yang nyata terhadap kadar zat terbang arang aktif (Tabel 6). Sebagai contoh adalah arang yang diaktivasi pada suhu $700^{\circ} \mathrm{C}$ dengan waktu aktivasi selama 30 menit (a1b1) sebesar 6,94\% tidak memberikan perbedaan yang nyata dibandingkan dengan arang yang diaktivasi pada suhu $800^{\circ} \mathrm{C}$ dengan lama waktu aktivasi 30 dan 90 menit (a2b1 dan a2b3) sebesar 6,41 dan 6,63\%.

Adapun proses pembentukan pori arang aktif (Gambar. 2) Secara fisik dari gambar tersebut nampak perlakuan panas mengakibatkan terjadinya pelepuhan pada dinding pori kayu, selanjutnya dengan menguapnya senyawa non karbon selama proses aktivasi bagian yang melepuh tadi akan sobek yang pada akhirnya akan terbentuk pori, baik berupa pori baru maupun pembesaran pori yang sudah terbentuk. Fenomena ini sesuai dengan yang dilakukan oleh Novicio, et al. (1998) dan Brasquet, et al. (2000). Pada prinsipnya pori yang terbentuk pada arang aktif terjadi secara fisik dan kimia. Pori yang terbentuk secara kimia terjadi dari hasil penataan kembali atom karbon akibat dari proses karbonisasi yang membentuk kristalit heksagonal, di mana makin tinggi suhu karbonisasi jumlah atom karbon yang membentuk kristalit makin banyak. (Hirose, et al., 2002; Kercher dan Nagle, 2003; dan Pari, 2004).

\section{F. Kadar Karbon Terikat}

Kadar karbon terikat arang aktif yang dihasilkan berkisar antara 48,85 - 83,50\% (Tabel 1). Kadar karbon terikat yang tidak memenuhi syarat standar Indonesia (Anonim, 1995) hanya arang yang diaktivasi pada suhu $700^{\circ} \mathrm{C}$ dengan waktu aktivasi selama 30 menit, karena kadarnya kurang dari $65 \%$. Berdasarkan penelaahan sidik ragam ternyata semua perlakuan dan interaksinya berpengaruh nyata terhadap kadar karbon terikat yang dihasilkan (Tabel 2). Kadar karbon terikat tertinggi (83,50\%) dihasilkan oleh arang yang diaktivasi pada suhu $900^{\circ} \mathrm{C}$ dengan lama waktu aktivasi 90 menit dan kadar karbon terikat yang terendah (48,85\%) dihasilkan oleh arang yang diaktivasi pada suhu $700^{\circ} \mathrm{C}$ dengan lama waktu aktivasi 30 menit. Tinggi rendahnya kadar karbon terikat yang dihasilkan selain dipengaruhi oleh tinggi rendahnya kadar abu dan zat terbang juga dipengaruhi oleh kandungan selulosa dan lignin yang dapat dikonversi menjadi atom karbon (Pari, 2004). Di samping itu, suhu aktivasi yang tinggi menunjukkan lebih banyak unsur bukan karbon ( terutama hydrogen) terdegradasi/teroksidasi karena stabilisasi panas untuk karbon lebih tinggi dari pada hydrogen dan unsur lain dalam kayu (arang). Kadar karbon yang tinggi dan kandungan zat terbang yang rendah menunjukkan arang aktif yang dihasilkan lebih bermuatan positif dengan sifat basa $(\mathrm{pH}=10,25)$. Apabila hasil ini dibandingkan dengan arang aktif komersial sebesar 46,16\%, maka kadar karbon hasil penelitian masih lebih rendah. 

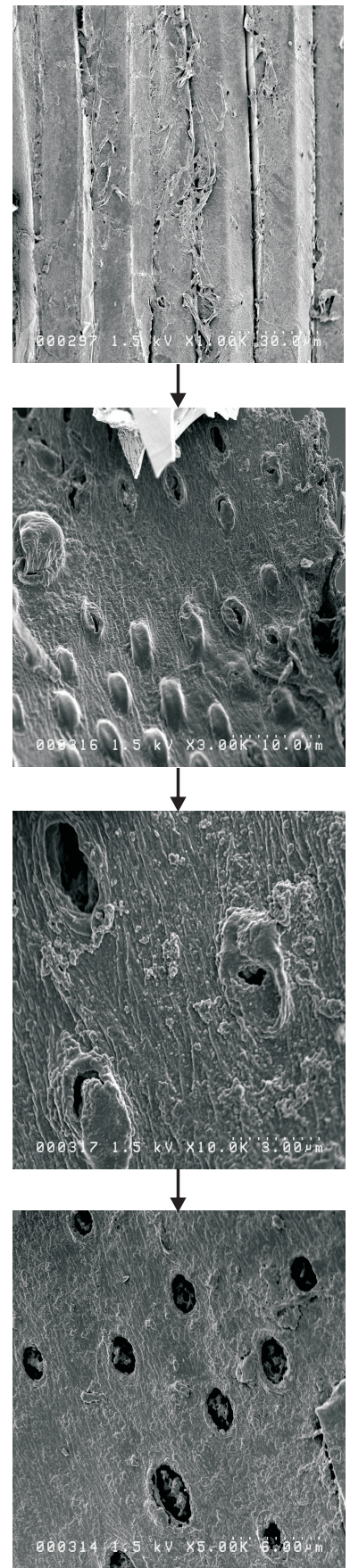

Gambar 2. Proses pembentukan pori pada aktivasi arang serbuk gergaji Figure 2. Formation of pores in the sawdust charcoal during its activation proces 
Uji sidik regresi menunjukkan bahwa makin lama suhu dan waktu aktivasi, kadar karbon terikat arang aktif yang dihasilkan makin rendah (Tabel 3 dan 4). Rendahnya kadar karbon ini menunjukkan banyak atom karbon yang bereaksi dengan uap air menghasilkan gas CO dan $\mathrm{CO}_{2}$ sehingga banyaknya atom karbon yang tersusun kembali membentuk struktur heksagonal sedikit.

Hasil uji BNJ menunjukkan bahwa tidak semua perlakuan dan interaksinya memberikan perbedaan yang nyata terhadap kadar karbon terikat arang aktif (Tabel 6). Sebagai contoh adalah arang yang diaktivasi pada suhu $800^{\circ} \mathrm{C}$ dengan waktu aktivasi selama 90 menit (a2b3) sebesar $76,69 \%$ tidak memberikan perbedaan yang nyata dibandingkan dengan arang yang diaktivasi pada suhu $900^{\circ} \mathrm{C}$ dengan lama waktu aktivasi 30 menit (a3b1) sebesar 74,33\%.

\section{G. Daya Serap Arang Aktif Terhadap Iodium}

Daya serap arang aktif terhadap iodium berkisar antara $687,40-1171,50 \mathrm{mg} / \mathrm{g}$ (Tabel 1). Semua daya serap arang aktif yang dihasilkan memenuhi syarat standar Indonesia (Anonim, 1995) kecuali arang yang diaktivasi pada suhu $700^{\circ} \mathrm{C}$ dengan lama waktu aktivasi 30 , 60 dan 90 menit karena daya serapnya kurang dari $750 \mathrm{mg} / \mathrm{g}$. Sedangkan yang memenuhi syarat standar Jepang (Anonim, 1967) adalah hanya arang aktif yang diaktivasi pada suhu $900^{\circ} \mathrm{C}$ dengan waktu aktivasi selama 90 menit, karena daya serapnya lebih dari $1050 \mathrm{mg} / \mathrm{g}$. Berdasarkan penelaahan sidik ragam ternyata semua perlakuan dan interaksinya berpengaruh nyata terhadap daya serap yang dihasilkan (Tabel 2). Daya serap iodium tertinggi $(1171,50$ $\mathrm{mg} / \mathrm{g}$ ) dihasilkan oleh arang yang diaktivasi pada suhu $900^{\circ} \mathrm{C}$ dengan lama waktu aktivasi 90 menit dan daya serap terendah $(687,40 \mathrm{mg} / \mathrm{g})$ dihasilkan oleh arang yang diaktivasi pada suhu $700^{\circ} \mathrm{C}$ dengan lama waktu aktivasi 30 menit. Tinggi rendahnya daya serap arang aktif terhadap iodium ini menunjukkan banyalnya diameter pori arang aktif yang berukuran 10 Angstrom $\left(A^{\circ}\right)$ dan permukaan arang aktifnya lebih bermuatan positif sehingga akan lebih menjerap senyawa yang bermuatan negatif. Hasil peneltian Dalvi and Ademoyero (1983) menyatakan bahwa arang aktif yang ditambahkan pada pakan ternak dapat menghilangkan racun dalam saluran pencernaan karena senyawa aflatoksin B1 diserap oleh arang aktif

Hasil ini tidak jauh berbeda dengan arang aktif dari serbuk gergaji kayu yang menggunakan $\mathrm{NH}_{4} \mathrm{HCO}_{3}$ sebagai bahan pengaktif (Pari, 1999). Namun apabila hasil ini dibandingkan dengan arang aktif komersial sebesar 643,04 mg/g, maka daya serap hasil penelitian tidak jauh berbeda.

Dari uji regresi terlihat bahwa makin suhu dan lama waktu aktivasi, daya serap arang aktif terhadap iodium yang dihasilkan cenderung meningkat (Tabel 3 dan 4). Peningkatan daya serap ini memperlihatkan bahwa atom karbon yang membentuk kristalit heksagonal makin banyak sehingga celah atau pori yang terbentuk di antara lapisan kristalit juga semakin besar.

Hasil uji BNJ menunjukkan bahwa tidak semua perlakuan dan interaksinya menyebabkan perbedaan daya serap arang aktif terhadap iodium yang nyata (Tabel 6). Sebagai contoh adalah arang yang diaktivasi pada suhu $800^{\circ} \mathrm{C}$ dengan lama waktu aktivasi 90 menit (a2b3) sebesar 1033,7 mg/g tidak memberikan perbedaan yang nyata dibandingkan dengan arang yang diaktivasi pada suhu $900^{\circ} \mathrm{C}$ dengan lama waktu aktivasi 30 dan 60 menit (a3b1 dan a3b2) sebesar 932,10 dan 1049,7 mg/g. 


\section{H. Daya Serap Arang Aktif Terhadap Benzena}

Daya serap arang aktif terhadap benzena berkisar antara 8,12 - 16,53\% (Tabel 1). Daya serap arang aktif terhadap benzena yang dihasilkan ini belum memenuhi syarat standar Indonesia (Anonim, 1995) karena masih kurang dari 25\%. Berdasarkan penelaahan sidik ragam ternyata suhu aktivasi dan interaksi antara suhu dan lama waktu aktivasi berpengaruh nyata terhadap daya serap yang dihasilkan (Tabel 2). Daya serap benzena terendah $(8,12 \%)$ dihasilkan oleh arang serbuk gergaji kayu yang diaktivasi pada suhu $700^{\circ} \mathrm{C}$ dengan lama waktu aktivasi 60 menit dan daya serap tertinggi (16,53\%) dihasilkan oleh arang serbuk gergaji yang diaktivasi pada suhu $800^{\circ} \mathrm{C}$ dengan lama waktu aktivasi 30 menit. Semakin besarnya daya serap arang aktif terhadap benzena pada kondisi aktifasi lebih besar (suhu tinggi dan waktu lebih lama) ini mencerminkan permukaan arang aktif menjadi lebih bersifat non polar sehingga dapat digunakan untuk menyerap polutan yang juga bersifat non polar seperti karbon tetra klorida. Hasil ini tidak jauh berbeda dengan arang aktif dari serbuk gergaji kayu yang menggunakan $\mathrm{NH}_{4} \mathrm{HCO}_{3}$ sebagai bahan pengaktif yang menghasilkan daya serap benzena antara 14,80 - 37,71\% (Pari, 1999). Apabila hasil ini dibandingkan dengan arang aktif komersial sebesar $2,78 \%$, maka daya serap benzena hasil penelitian masih lebih tinggi.

Hasil uji BNJ menunjukkan bahwa tidak semua perlakuan dan interaksinya menyebabkan perbedaan yang nyata daya serap arang aktif terhadap benzena (Tabel 6). Sebagai contoh adalah arang yang diaktivasi pada suhu $800^{\circ} \mathrm{C}$ dengan lama waktu aktivasi 60 menit (a2b2) sebesar 15,58\% tidak memberikan perbedaan yang nyata terhadap arang yang diaktivasi pada suhu $900^{\circ} \mathrm{C}$ dengan lama waktu aktivasi 60 menit (a3b2) sebesar 15,00\%.

\section{Daya Serap Arang Aktif Terhadap Metil Tetra Klorida $\left(\mathrm{CHCl}_{3}\right)$}

Daya serap arang aktif terhadap $\mathrm{CHCl}_{3}$ berkisar antara 18,60 - 47,56\% (Tabel 1). Daya serap arang aktif terhadap $\mathrm{CHCl}_{3}$ yang memenuhi persyaratan departemen kesehatan di dalam Sudradjat dan Soleh (1994) adalah hanya arang yang diaktivasi pada suhu $900^{\circ} \mathrm{C}$ dengan lama waktu aktivasi 60 menit karena daya serapnya lebih dari 40\%. Berdasarkan penelaahan sidik ragam ternyata semua perlakuan dan interaksinya berpengaruh nyata terhadap daya serap yang dihasilkan (Tabel 2). Daya serap $\mathrm{CHCl}_{3}$ terendah (18,60\%) dihasilkan oleh arang yang diaktivasi pada suhu $700^{\circ} \mathrm{C}$ dengan lama waktu aktivasi 30 menit dan daya serap tertinggi $(47,56 \%)$ dihasilkan oleh arang yang diaktivasi pada suhu $900^{\circ} \mathrm{C}$ dengan lama waktu aktivasi 60 menit. Lebih besarnya daya serap arang aktif terhadap $\mathrm{CHCl}_{3}$ ini mencerminkan permukaan arang aktif akibat kondisi aktifasi yang lebih besar juga bisa bersifat lebih polar disamping non-polar yang juga terjadi, berdasarkan uji daya serap benzena sebelumnya sehingga dapat digunakan untuk menyerap polutan yang juga bersifat polar seperti aldehida. Dari uji regresi terlihat bahwa makin lama waktu aktivasi, daya serap arang aktif terhadap $\mathrm{CHCl}_{3}$ yang dihasilkan meningkat (Tabel 3). Peningkatan daya serap ini memperlihatkan permukaan arang aktif lebih bersifat polar. 
Table 3. Persamaan regresi hubungan antara suhu aktivasi (X1) terhadap sifat arang aktif (Y)

Table 3. Regressions between activation temperature (X1) and activated charcoal properties $(Y)$

\begin{tabular}{|l|c|c|c|}
\hline \multicolumn{1}{|c|}{ Sifat (Properties) } & Regresi (Regression) & $\begin{array}{c}\text { Koefisien korelasi } \\
\text { (Coeficientc correlation), } r\end{array}$ & $\begin{array}{c}\text { F-hitung } \\
(\text { F-calc })\end{array}$ \\
\hline Rendemen (Yield), \% & $\mathrm{Y}=83,38-0,07 \mathrm{X} 1$ & $-0,9819$ & $4,0802^{*}$ \\
\hline $\begin{array}{l}\text { Kadar air (Moisture con- } \\
\text { tent), } \%\end{array}$ & $\mathrm{Y}=-15,50+0,03 \mathrm{X} 1$ & 0,9011 & $4,2843^{*}$ \\
\hline Kadar abu (Ash content), \% & $\mathrm{Y}=-46,86+0,08 \mathrm{X} 1$ & 0,9346 & $6,9091^{* *}$ \\
\hline $\begin{array}{l}\text { Kadar zat terbang } \\
\text { (Volatile matter), \% }\end{array}$ & $\mathrm{Y}=12,74-0,01 \mathrm{X} 1$ & $-0,6546$ & 0,7528 \\
\hline $\begin{array}{l}\text { Kadar karbon terikat } \\
\text { (Fixed carbon), \% }\end{array}$ & $\mathrm{Y}=134,16-0,07 \mathrm{X} 1$ & $-0,9404$ & $7,5745^{* *}$ \\
\hline $\begin{array}{l}\text { Daya serap iodium } \\
\text { (Adsorptive capacity on } \\
\text { iodine), mg/g }\end{array}$ & $\mathrm{Y}=-454,33+1,70 \mathrm{X} 1$ & 0,9608 & $12,0088^{* *}$ \\
\hline $\begin{array}{l}\text { Daya serap benzena } \\
\text { (Adsorptive capacity on } \\
\text { benzene), \% }\end{array}$ & $\mathrm{Y}=-1,91+0,02 \mathrm{X} 1$ & 0,4883 & 0,3133 \\
\hline $\begin{array}{l}\text { Daya serap CHCl } \\
\text { (Adsorptive capacity on }\end{array}$ & $\mathrm{Y}=-19,56+0,06 \mathrm{X} 1$ & 0,8355 & 2,3134 \\
CHCl $), \%$
\end{tabular}

Keterangan (Remarks): ** = Sangat nyata (Highly significant); * = Nyata (Significant)

Hasil uji BNJ menunjukkan bahwa tidak semua perlakuan dan interaksinya menyebabkan perbedaan daya serap arang aktif yang nyata terhadap $\mathrm{CHCl}_{3}$ (Tabel 6). Sebagai contoh adalah arang yang diaktivasi pada suhu $800^{\circ} \mathrm{C}$ dengan lama waktu aktivasi 60 menit (a2b2) sebesar 34,65\% tidak memberikan perbedaan yang nyata terhadap arang yang diaktivasi pada suhu $800^{\circ} \mathrm{C}$ dengan lama waktu aktivasi 30 dan 90 menit (a2b1 dan a2b3) sebesar 35,99 dan 35,44\%. 
Table 4. Persamaan regresi hubungan antara waktu aktivasi (X2) terhadap sifat arang aktif (Y)

Table 4. Regressions between activation duration (X2) and activated charcoal properties (Y)

\begin{tabular}{|c|c|c|c|}
\hline Sifat (Properties) & Regresi (Regression) & $\begin{array}{l}\text { Koefisien korelasi } \\
\text { (Coeficient orrelation) }\end{array}$ & $\begin{array}{c}\text { F-hitung } \\
(F \text {-calc })\end{array}$ \\
\hline Rendemen (Yield), \% & $\mathrm{Y}=39,58-0,21 \mathrm{X} 2$ & $-0,9898$ & $48,1800^{* *}$ \\
\hline $\begin{array}{l}\text { Kadar air (Moisture con- } \\
\text { tent), } \%\end{array}$ & $\mathrm{Y}=11,63+0,04 \mathrm{X} 2$ & 0,6919 & 0,9164 \\
\hline Kadar abu (Ash content), \% & $\mathrm{Y}=8,35+0,17 \mathrm{X} 2$ & 0,9717 & $16,9075^{* *}$ \\
\hline $\begin{array}{l}\text { Kadar zat terbang } \\
\text { (Volatile matter), \% }\end{array}$ & $\mathrm{Y}=5,81+0,04 \mathrm{X} 2$ & 0,9654 & $13,5563^{* *}$ \\
\hline $\begin{array}{l}\text { Kadar karbon terikat } \\
\text { (Fixed carbon), \% }\end{array}$ & $\mathrm{Y}=86,95-0,24 \mathrm{X} 2$ & $-0,9787$ & $22,6209 * *$ \\
\hline $\begin{array}{l}\text { Daya serap iodium } \\
\text { (Adsorptive capacity on } \\
\text { iodine), } \mathrm{mg} / \mathrm{g}\end{array}$ & $\mathrm{Y}=782,88+2,10 \mathrm{X} 2$ & 0,9776 & $21,6045^{* *}$ \\
\hline $\begin{array}{l}\text { Daya serap benzena } \\
\text { (Adsorptive capacity on } \\
\text { benzene), \% }\end{array}$ & $\mathrm{Y}=12,54-0,003 \mathrm{X} 2$ & $-0,2195$ & 0,0509 \\
\hline $\begin{array}{l}\text { Daya serap } \mathrm{CHCl}_{3} \\
\text { (Adsorptive capacity on } \\
(\mathrm{CHCl} 3 \text { ), \% }\end{array}$ & $\mathrm{Y}=27,40+0,05 \mathrm{X} 2$ & 0,3741 & 0,1626 \\
\hline $\begin{array}{l}\text { Daya serap biru metilena } \\
\text { (Adsorptive capacity on } \\
\text { methylene blue), } \mathrm{mg} / \mathrm{g}\end{array}$ & $\mathrm{Y}=73,72+0,65 \mathrm{X} 2$ & 0,9445 & $9,2724 * *$ \\
\hline
\end{tabular}

Keterangan (Remarks): ** = Sangat nyata (Highly significant); * = Nyata (Significant)

\section{Daya Serap Arang Aktif Terhadap Biru Metilena}

Daya serap arang aktif terhadap biru metilena berkisar antara 32,5 - 149,98 mg/g (Tabel 1). Daya serap arang aktif terhadap biru metilena yang memenuhi syarat standar Indonesia (Anonim, 1995) adalah hanya arang yang diaktivasi pada suhu $900^{\circ} \mathrm{C}$ dengan lama waktu aktivasi 60 dan 90 menit, karena daya serapnya lebih dari $120 \mathrm{mg} / \mathrm{g}$. Berdasarkan penelaahan sidik ragam ternyata semua perlakuan dan interaksinya berpengaruh nyata terhadap daya serap yang dihasilkan (Tabel 2). Daya serap biru metilena terendah $(32,52$ $\mathrm{mg} / \mathrm{g}$ ) dihasilkan oleh arang yang diaktivasi pada suhu $700^{\circ} \mathrm{C}$ dengan lama waktu aktivasi 30 menit, dan daya serap tertinggi $(149,98 \mathrm{mg} / \mathrm{g})$ dihasilkan oleh arang yang diaktivasi pada suhu $900^{\circ} \mathrm{C}$ dengan lama waktu aktivasi 90 menit. Besarnya daya serap arang aktif terhadap biru metilena ini menggambarkan diameter pori yang terbentuk banyak yang berukuran $15 \mathrm{~A}^{\circ}$, selain itu arang aktif ini juga dapat digunakan untuk menjernihkan polutan yang mengandung zat warna yang bersifat polar. Dari uji regresi terlihat bahwa makin tinggi suhu dan lama waktu aktivasi, daya serap arang aktif terhadap biru metilena yang dihasilkan meningkat (Tabel 3 dan 4). Peningkatan daya serap ini mengimplikasikan lagi bahwa permukaan arang aktif menjadi lebih bersifat polar, akibat kondisi aktifasi yang lebih besar. 
Hasil uji BNJ menunjukkan bahwa tidak semua perlakuan dan interaksinya menyebabkan perbedaan yang nyata daya serap arang aktif terhadap biru metilena (Tabel 6). Sebagai contoh adalah arang yang diaktivasi pada suhu $700^{\circ} \mathrm{C}$ dengan lama waktu aktivasi 90 menit (a1b3) sebesar 117,00 mg/g tidak memberikan perbedaan yang nyata terhadap arang yang dihasilkan pada suhu aktivasi $800^{\circ} \mathrm{C} 30$ dan 90 menit (a2b1 dan a2b3) sebesar 116,60 dan $118,77 \mathrm{mg} / \mathrm{g}$.

\section{J. Kondisi Optimum Pembuatan Arang Aktif}

Kondisi optimum didefinisikan sebagai kondisi perlakuan yang dapat memberikan hasil arang aktif terbaik, didasarkan atas besarnya rendemen yang dihasilkan dan daya serap arang aktif terhadap iodium (Hartoyo et al. 1990). Sehubungan dengan hal tersebut maka kondisi optimum untuk membuat arang aktif dari serbuk gergajian kayu pada percobaan ini adalah arang yang diaktivasi pada suhu $800^{\circ} \mathrm{C}$ selama 60 menit (Tabel 5 dan 6). Pada perlakuan ini rendemen yang dihasilkan menghasilkan rendemen sebesar 30,80\%, kadar air 15,03\%, kadar abu 14,23\%, kadar zat terbang 8,95\%, kadar karbon terikat 76,82\%. Daya serap arang aktif terhadap benzena sebesar 15,58\%, $\mathrm{CHCl}_{3}$ sebesar 34,65\% dan daya serap terhadap biru metilena sebesar 112,18 mg/g. Atas dasar besarnya daya serap terhadap biru metilina, maka arang aktif dari serbuk gergaji ini dapat digunakan untuk penjernihan zat warna, dan juga daya serap arang aktif terhadap iodium sebesar $921,85 \mathrm{mg} / \mathrm{g}$. Nilai daya serap ini memenuhi syarat standar Indonesia (Anonim, 1995) tetapi tidak memenuhi syarat standar Jepang (Anonim, 1967) karena daya serapnya kurang dari $1050 \mathrm{mg} / \mathrm{g}$. Kondisi pembuatan arang aktif yang daya serapnya memenuhi syarat standar Jepang adalah arang yang diaktivasi pada suhu $900^{\circ} \mathrm{C}$ dengan waktu aktivasi 90 menit, menghasilkan daya serap iodium sebesar $1171,5 \mathrm{mg} / \mathrm{g}$.

Tabel 5. Rendemen dan daya serap iodium arang aktif serbuk gergaji Table 5. Yield and iodine adsorption capacity of activated sawdust charcoal

\begin{tabular}{|c|c|c|c|c|}
\hline 1 & 2 & 3 & 4 & 5 \\
\hline 700 & 30 & 41,00 & 687,4 & 281,83 \\
& 60 & 30,53 & 708,6 & 216,34 \\
& 90 & 28,66 & 734,7 & 210,57 \\
\hline 800 & 30 & 31,00 & 941,9 & 282,83 \\
& 60 & 30,80 & $921,81)$ & 216,34 \\
& 90 & 24,33 & 1033,7 & 210,57 \\
\hline 900 & 30 & 29,66 & 932,1 & 276,46 \\
& 60 & 17,00 & 1047,7 & 178,45 \\
& 90 & 11,33 & $1171,52)$ & 132,73 \\
\hline
\end{tabular}

Keterangan (Remarks) : 1 = Suhu aktivasi (Activation temperature); 2 = Waktu aktivasi (Activation duration); $3=$ Rendemen (Yiled); 4 = Daya serap iodium (Adsorptive capacity of iodine); $5=$ Kondisi optimum (Optimum cndition)

${ }^{1)}$ Kondisi optimum yang bisa memenuhi persyaratan standar Indonesia (Optimum condition that could meet Indonesia Standard)

${ }^{2)}$ Kondisi optimum yang bisa memenuhi persyaratan standar Jepang (Optimum condition that could meet Japan Standard) 


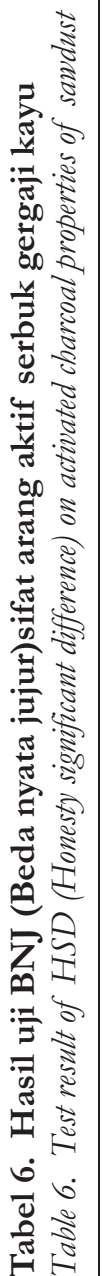

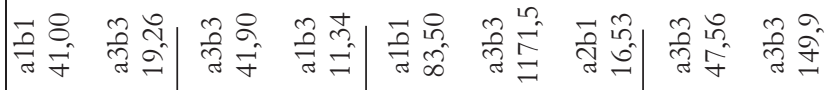

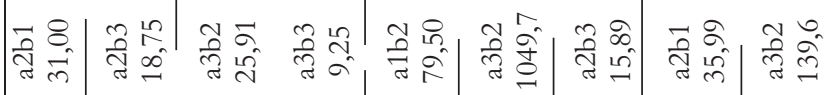

ङ

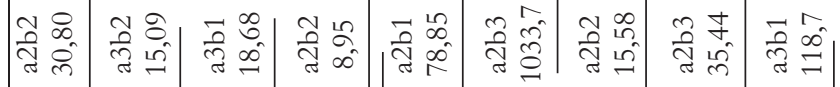

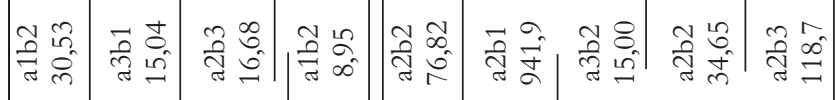

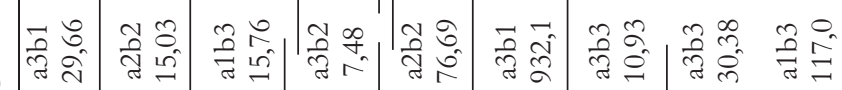

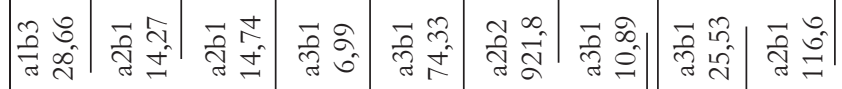

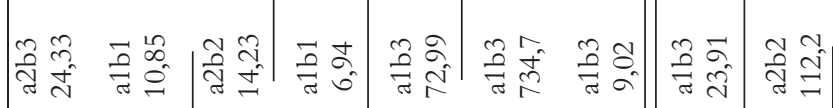

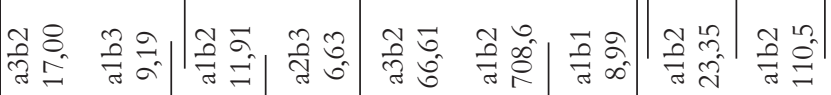

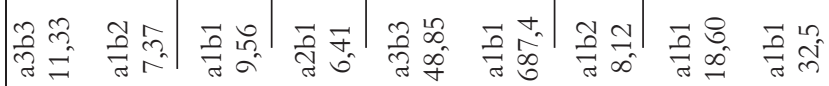

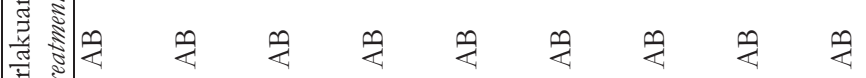




\section{KESIMPULAN}

Serbuk gergaji kayu dapat dibuat arang dan dijadikan arang aktif karena kadar karbon terikatnya memenuhi persyaratan dengan kadarnya yang lebih dari $70 \%$ yaitu sebesar $72,32 \%$. Sifat lainnya adalah kadar air sebesar 3,07\%, kadar abu 4,50\%, kadar zat terbang 23,68\% dan rendemen arang yang dihasilkan sebesar $21,27 \%$.

Kondisi optimum untuk membuat arang aktif dengan kualitas terbaik dihasilkan pada suhu $800^{\circ} \mathrm{C}$, dengan lama waktu aktivasi 60 menit, menghasilkan rendemen sebesar $30,80 \%$, kadar air 15,03\%, kadar abu 14,23\%, kadar zat terbang 8,95\%, kadar karbon terikat 76,82\%. Pada kondisi tersebut daya serap arang aktif terhadap benzena sebesar $15,58 \%, \mathrm{CHCl}_{3}$ $34,65 \%$, iodium $921,85 \mathrm{mg} / \mathrm{g}$ dan daya serap terhadap biru metilena 112,18 mg/g. Didasarkan atas besarnya daya serap terhadap biru metilina, maka arang aktif dari serbuk gergaji ini dapat digunakan untuk penjernihan zat warna. Kondisi pembuatan arang aktif yang daya serapnya memenuhi syarat standar Jepang adalah arang yang diaktivasi pada suhu $900^{\circ} \mathrm{C}$ dengan waktu aktivasi 90 menit, menghasilkan daya serap iodium sebesar 1171,5 mg/g lebih besar dari yang dipersyaratkan yaitu sebesar $1050 \mathrm{mg} / \mathrm{g}$. Berdasarkan sifat dan besarnya daya serap terhadap metilena biru maka arang aktif dari serbuk gergaji ini dapat digunakan sebagai penjernih zat warna dan campuran pakan ternak ayam.

\section{DAFTAR PUSTAKA}

Anonim. 1967. Japanese Industrial Standard. Testing methode for activated carbon. JIS- K1474. Japanese Standards Association, Tokyo.

1985. Industrial charcoal making. Food and Agriculture Organization of The United Nations, Rome.

1995. Arang aktif teknis. Badan Standardisasi Nasional, Jakarta. SNI 06-3730-1995.

1982. Standar methode coal and coke. ASTM, Philadelphia.

.1978. Standar methode of water. American Water Works Association, Colorado. B 600-78.

Brasquet, C., B. Rousseau., H.E. Szwarckopf and P.L. Cloirec. 2000. Observation of activated carbon fibres with SEM and AFM correlation with adsorption data in aqueous solution. Carbon 38: 407-422. Elsevier, UK

Dalvi R. R and A.A. Ademoyero. 1983. Toxic effect of aflatoxin B1 in chickens given feed contaminated with Aspergillus flavus and reduction of toxicity by activated charcoal. Avian disease. 28 (1): 61-69.

Hartoyo, Hudaya, dan Fadli. 1990. Pembuatan arang aktif dari tempurung kelapa dan kayu bakau dengan cara aktivasi uap. Jurnal Penelitian Hasil Hutan. 18 (1): 8-16. Pusat Litbang Hasil Hutan. Bogor.

Hirose, T., Fujino, T., Fan, T., Endo, H., Okabe, T. and M. Yoshimura. 2002. Effect of carbonization temperature on the structural changes of wood ceramics impregnated with liquefied wood. Carbon 40: 761-765. Elsevier, UK. 
Kercher, A. and D.C. Nagle. 2003. Microstructural evolution during charcoal carbonization by X-ray diffraction analysis. Carbon 41: 15-27. Elsevier, UK.

Komarayati, S., Hendra, D dan Gusmailina. 1998. Pembuatan arang aktif dari biomassa hutan. Buletin Penelitian Hasil Hutan. 16 (2): 61-68. Pusat Litbang Hasil Hutan. Bogor.

Pari, G. 1992. Pembuatan arang aktif dari serbuk gergajian sengon untuk penjernih air. Jurnal Penelitian Hasil Hutan. 10(5): 141-149. Pusat Litbang Hasil Hutan Bogor, Bogor.

. 1996. Pembuatan arang aktif dari serbuk gergajian tusam untuk penjernih air limbah industri pulp kertas dan air sumur. Buletin Penelitian Hasil Hutan. 14(2): 69-759. Pusat Litbang Hasil Hutan Bogor, Bogor.

Buchari dan A. Sulaeman. 1996. Pembuatan dan kualitas arang aktif dari kayu sengon sebagai bahan adsorben. Buletin Penelitian Hasil Hutan. 14(7): 274- 289. Pusat Litbang Hasil Hutan Bogor. Bogor.

1999. Karakterisasi arang aktif dari arang serbuk gergajian sengon dengan bahan pengaktif $\mathrm{NH}_{4} \mathrm{HCO}_{3}$. Buletin Penelitian Hasil Hutan. 17 (2): 89-100. Pusat Litbang Hasil Hutan. Bogor.

- Hartoyo dan Nurhayati. 2000. Kemungkinan pemanfaatan arang aktif kulit kayu Acacia mangium Willd untuk pemurnian minyak kelapa sawit. Buletin Penelitian Hasil Hutan. 18(1): 40-53. Pusat Penelitian Hasil Hutan, Bogor.

, dan H. Roliadi. 2004. Alternative technology for the utilization of biomass waste from wood industries. Proceeding of the International workshop on better utilization of forest biomass for local community and environments. Resrearch and Development Center for Forest Products Technology, Bogor.

. 2004. Kajian struktur arang aktif dari serbuk gergaji kayu sebagai adsorben emisi formaldehida kayu lapis. Disertasi. Sekolah Pascasarjana Insitut Pertanian Bogor, Bogor.

, Hendra, D dan R. A. Pasaribu. 2006. Pengaruh lama waktu aktivasi dan konsentrasi asam fosfat terhadap mutu arang aktif kulit kayu Acacia mangium. Jurnal Penelitian Hasil Hutan, Bogor. 24 (1):33-46.

Novicio, L.P., Hata, T., Kajimoto, T., Imamura, Y and S. Ishihara. 1998. Removal of mercury from aqueous solutions of mercuric chloride using wood powder carbonized at high temperature. Journal of Wood Research. No 85: 48-55. The Japan Wood Research Society, Japan.

Smisek, M and S. Cerny. 1970. Active carbon: Manufacture, properties and application. Elsevier Publishing Company, New York.

Sudjana. 1980. Disain dan eksperimenat analisis. Tarsito, Bandung.

Sudradjat dan S. Soleh. 1994. Petunjuk teknis pembuatan arang aktif. Pusat Litbang Hasil Hutan dan Sosial Ekonomi Kehutanan, Bogor.

Takahashi, T and T. Hirowaka. 2009. Charcoal application for poultry farming. 1 st Asia Pacific Biochar Conference. Gold Coast, Australia. 